\title{
横浜における輸出生糸の検査に関わる建築に見られた遮光装置 \\ THE SHADING EQUIPMENT THAT PUTTED IN THE WINDOW FOR TESTING THE EXPORT RAW SILK IN YOKOHAMA
}

\author{
二 村 悟*, 後藤 治** \\ Satoru NIMURA and Osamu GOTO
}

\begin{abstract}
In Yokohama many companies exported raw silk at the end of $19^{\text {th }} \mathrm{c}$. In the beginning of $20^{\text {th }} \mathrm{c}$. some trading companies had the shading equipments that putted in the window for testing the quality of the raw silk. That equipment was invented for testing the great deal raw silk in 1901 when the national institute for testing the raw silk was enlarged. After that the equipment prevailed to the trading companies. In Yokohama at the end of $19^{\text {th }} \mathrm{c}$. the tea trading companies used the similar equipment called "HIYOKE" for testing the quality of the tea. The equipments for the raw silk followed ones for the tea.
\end{abstract}

\section{Keywords : $\quad$ Yokohama City, Raw silk, Equipment, Industrial Heritage, Tea Industry 横浜市，生系，建築設備，産業遺産，茶産業}

\section{1 はじめに}

明治期の横浜市内には、輸出生系に携わる商社を中心に、特異な 建築設備が外壁面に付設している建物が存在した。この設備は、生 産者から持ち込まれた生糸の出来栄えを判別するためのものだった。 生系生産や養虫に関わる民家建築については、今和次郎、伊藤鄭爾 を始めとして多くの研究 1)が為されてきた。また、横浜の都市や建 筑についても多くの研究がある 2)。けれども、横浜における輸出生 系に関わる建築については、現在まで学術的にはほとんど注目され ておらず3、その設備に注目した研究も無い。

本稿では、横浜に見られた輸出生采の検查に関わる建築の設備に 着目し、その特徽やそれが普及した背景等を知ることを目的とする。

\section{2 遮光装置の壮様と用語}

この設備の構造や機能については、昭和 8 年刊行『生系品位検査 並に格付の実際』(以下、「検查仕様」と呼ぶ。また『』内は後掲の 参考文献とする。）に以下のように触れられている。

肉眼検查室は室の北方中央の壁に空を設け、他の三方は黒幕張り として室内の反射光線を防ぐ様装置せられたる長方形の部屋で、 空は床面から約九十糎（約三尺）の所に幅約一米突二十粝（約四 尺)、高さ約一米突四十粝（約四尺六寸）の大きさ (中略)。空外 の反射光線を防ぐ為に空の外側下部からは内面黒塗の遮光装置を 四十五度の角度に上部に向って斜に突出せられて居ります。斯様 に作られてあるので空外の反射光線の侵入は防がれ、光線は只北 方天空のみから入り来るのであります。4)
このように、設備は「遮光装置」と呼ばれており、生系の肉眼検 査をするための部屋につくられていたことがわかる（以下、本稿で はこの設備を「遮光装置」という)。肉眼検査について同書は、

生系品位決定上その補助となるもので荷口の総荷について、肉眼 と手触によって整理の状態及び性状を検査(中略)性状のうち色相 は種類及び着色程度について光沢は種類及び光沢程度について

検查を行うものとしている。6

\section{3 横浜における遮光装置}

\section{3-1 桧画資料と古写衰に見る遮光装昷}

遮光装置の現存例は無いが、数種類の古写真に確認できる。 A:『THE JAPAN ADVERTISER DIRECTORY』、B:『実業之横浜』、 C:『スレート商会写真帳』、D：『横浜生系検查所六十年史』、E：『建 筑寫薑類聚』、F: 『PRESENT-DAY IMPRESSIONS OF JAPAN』、 G:『日本㫤系業史 第二巻』、H:『横浜生系検査所建設記録』、I：『横 浜銅版画』7)所収の『横浜諸会社諸商店之図』である。

A は、明治 36 年に発行された日本国内に在住した外国人の人名 録で、建築や地図の図版が揭載されており、その中で 1 点、251 番・ 富士貿易商会 A-1［図 1] に確認できる。

B は、明治 44 年 10 月に発行された横浜の商業に関わる情報を揭 載した写真入の月刊誌で、 216 番・矢野上甲合名会社虫系部 B-1 [図 2]に確認できる。B-1 は、同じ店舗の上下に 2 箇所の遮光装置が確
* 工学院大学工学部建築都市デザイン学科 客員研究員・博士 (工学)

** 工学院大学工学部建築都市デザイン学科教授・博士 (工学)
Guest Researcher, Kougakuin University, Dr. Eng.

Prof., Kougakuin University, Dr. Eng. 
認できるので、下を B-1(1)、上をB-1(2)とする。

$\mathrm{C}$ は、明治 42 年に発行されたスレート商会の施工例を揭載した 写真帳で、256 番・ウインクラー商会 C-1 [図 3] に確認できる。

$\mathrm{D}$ は、昭和 34 年に発行された横浜生系検査所（以下、「検査所」 という。）の変遷を記したもので、その中で 2 点、「正量部拡張増築」 D-1 [図 4] 8)、「品位部拡張増築」D-2［図 5] に確認できる。

$\mathrm{E}$ は、大正 6 年発行の用途別に近代建築の図版を集めたもので、 177 番·三井物産横浜支店 E-1 [図 6] に確認できる。E-1 は、2-3 階の 2 籄所に確認できるので、下を E-1(1)、上を E-1(2)とする。『建 築雑誌 305 号』では、E-1 を「生系試験室」に続く「見本室」とし て、「二階の一隅倉庫に通ずる路を兼て施設し拝見空を付す」として いる。これによって、肉眼検查が当時「扯見」とも呼ばれ、遮光装 置が付いた検査に用いる空を「遅見空」と呼んだことがわかる。9

$\mathrm{F}$ は、大正 8 年に発行された日本各地の産業とその風景を撮影し たもので、その中で 7 点、47 番・クーパー商会 F-1 [図 7]、90 番 • シーベル＆ブレンワルト商会 F-2 [図 8]、93 番・ウィトコフスキー 商会 F-3 [図 9]、183 番・バルモン商会 F-4 [図 10]、200 番・ア イザックス兄弟商会 F-5 [図 11]、225 番・中外貿易商会 F-6［図 12]、横浜貿易倉庫 G 倉庫 F-7［図 13］に確認できる。

$\mathbf{G}$ は、昭和 10 年発行の蛋系業について記した全 5 巻の総合書で、 その中で 1 点、帝国亘系倉庫株式会社 G-1 [図 14] に確認できる。

H は、大正 15 年竣工で、昭和 7 年の增築時に図面や写真で記録 したもので、総荷検查室 H-1 [図 15］に見られる。立平面図では、 1 階の総荷検查室に、同一形状の遮光装置が 13 筒所確認できる。

I は、明治 $16 \sim 24$ 年に描かれて掞り、生系・茶貿易の中心となっ た日本人町に建つ商家を描いた資料で、生系売込直輸商・貿易商会 I-1［図 16］のみ確認できる。また、Iの『横浜銅版画』にともに所 収されている『日本絵入商人録』には、F-2 の「横浜新九十番内部 之図 シーベル・ブレンワルド商会」が紹介されている。そこには [図 8]と同じ建物が描かれ、遮光装置のようなものが見られる 10)。

このように、遮光装置は明治 30 年代から昭和期まで幅広い時代 に見られる。

\section{3-2 遮光装量の年代と仕様}

遮光装置の設置時期を一覧で示したものが [表 1]、収集した遮光 装置の仕様を一覧で示したものが [表 2]、遮光装置の側面形状を年 代順にまとめ、縮尺を合わせて作図したものが［表 3］である。

[表 1] から、設置年代は I-1 を除くと明治 20 年代初頭まで遡る ものはない。また、検查仕様が刊行された昭和 8 年には、既に遮光 装置が必要な設備として位置付けられていたことがわかる。

設置位置・場所は、18 例中 12 例が主屋、6 例が倉庫と見られる建 物である。2 階以上の設置が 18 例中 13 例、 1 階が 5 例である。A-1、

B-11、F-4 が出入口脇や敷地内の脇道沿いである。

側面形状は、11 例が三角形である。B-1(1)、E-1(2、F-3、F-4、

F-7、H-1については、特徴的な形状を持つ。

幅は、最大が B-1(1)・I-1 05 尺、 4 尺が 4 例、3 尺が 4 例、 2 尺 が 7 例である。

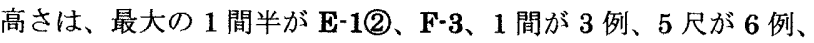
4 尺が 6 例、3 尺が 1 例である。

表面仕様は、F-6 のように板材で箱型に構築したもの、板張りを
栈で押える仕様などが見られる。

\section{3-3 遮光装置の特鹳}

このように、遮光装置を分析すると以下のような特徵が見られる。 設置場所が 2 階に多い理由は、肉眼検査は多くの荷の見本をそれ ぞれ検查するので広い場所が必要とされる。運ばれた荷を事務手続 きし、1 階で「括解き」11)と呼ばれる荷解きをする。このため、広 い場所が確保できない商社は、肉眼検査を上階で行ったと考えられ る。検查所 $(\mathrm{H})$ は、 $\mathrm{RC}$ 造平屋建ての荷解場を 700 坪確保している ${ }^{12)}$ 。 庁舎の延床面積が 831.1 坪なので、必要とする面積の大きさがわか る。

A-1 は [図 1] を見るように建築面積が小さく、通路を挟んで別 棟の建物が隣接している。このため、通常、荷解場と検查場とは同 じ建物内にあるが、別棟にあった可能性もある。

検査仕様に記されるように、肉眼検査には光が重視された。『検查 時報 No.205』では、天然光線と人工光線の見え方の違いを触れて いる。本来は天然光線が良しとされたが、近代化により人工光線と なる ${ }^{13 !}$ 。遮光装置が上階に多いのは、遮るものが減り、光を取り込 みや寸かったことも、その原因のひとつではないかと考えられる。

\begin{tabular}{|c|c|c|c|}
\hline 番号 & 上限 & 下限 & 凡例 \\
\hline$A-1$ & 明治 27 年桂 1 & 明治 36 年 & 掣时: 刊行年 \\
\hline$B-1$ & \multicolumn{2}{|c|}{ 明治 44 年 $\Delta$ 柱 2} & {$[\Delta]:$ 解果年 } \\
\hline$C-1$ & 明治 26 年口吅 & 明治 42 年 & 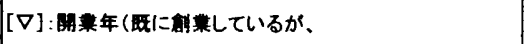 \\
\hline $\mathrm{D}-1$ & \multicolumn{2}{|c|}{ 明治 34 年o } & 改めて横浜で開策した年） \\
\hline $\mathrm{D}-2$ & \multicolumn{2}{|c|}{ 大正 7 年O } & [ロ] : 社名変更による上限・下限 \\
\hline $\mathrm{E}-1$ & 明治 44 年O & 大正 6 年 & [ᄆ口] : 存在が確億できた年 \\
\hline $\mathrm{F}-1$ & 明治 42 年 $\Delta$ & 大正 8 年 & {$[0]:$ 蟙工年 } \\
\hline $\mathrm{F}-2$ & 明治 26 年 $\Delta$ & 大正 8 年 & [OO]:生系軜出を開始した年 \\
\hline $\mathrm{F}-3$ & 明治 24 年 $\Delta$ & 大正 8 年 & {$[\nabla \nabla]:$ 用菓年 } \\
\hline $\mathrm{F}-4$ & 大正 3 年 $\nabla$ & 大正 8 年 & \\
\hline$F-5$ & 大正元年 $\nabla$ & 大正 8 年 & \\
\hline $\mathrm{F}-6$ & 大正 6 年 $\Delta$ & 大正 8 年 & \\
\hline$F-7$ & 明治 29 年。 & 大正 8 年 & \multirow{4}{*}{ 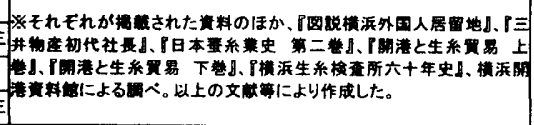 } \\
\hline G-1 & 大正 15 年 $\Delta$ & 昭和 10 年 & \\
\hline $\mathrm{H}-1$ & \multicolumn{2}{|c|}{ 昭和 7 年O } & \\
\hline $1-1$ & 明治 13 年 $\Delta$ & 明治 24 年 & \\
\hline & $\begin{array}{l}-1 \text { は、明治 } 26 \text { 年刊 } \\
\text {-1 は、明治 } 23 \sim 33 \\
\text { 在するので、上限は }\end{array}$ & 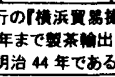 & 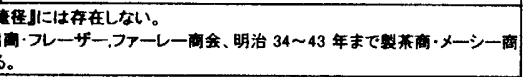 \\
\hline
\end{tabular}

[表 2]遮光装而一管

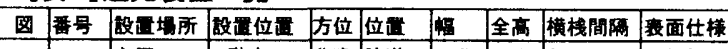

\begin{tabular}{|c|c|c|c|c|c|c|c|c|c|}
\hline & & & & & & & & . & \\
\hline 1 & $A-1$ & 主漏 & 2 胿密 & 北東 & 妿道 & 2 尺 & 4 尺 & なし & 一枚板で箱型に構築 \\
\hline 2 & $8-1(1)$ & 主屋 & 入口左费 & 北西 & 表通り & 5 尺 & 4 R & & 板强り格子栈押文 \\
\hline & $B-1(2)$ & 主策 & 2 陧密 & 北西 & 表通り & 4 R & 4 R & & 板彋り格子栈押え \\
\hline 3 & $\mathrm{C}-1$ & 主䙓 & 2 䄸密 & 軍南 & 妻通り & 2 尺 & 5 尺 & - & 堅板張り横栈押え \\
\hline 4 & $D-1$ & 主虐 & 1 䣝空 & 南果 & 㤗通り & 2 R & 1 間 & - & - \\
\hline 5 & $D-2$ & 主粴 & 1 眣空 & 南東 & 裹通り & 4 尺 & 5 尺 & 1 R & 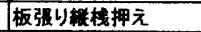 \\
\hline 6 & $E-11$ & 主鹿 & 2 階空 & 北東 & 尧通り & 2 尺 & 1 間 & なし & 一枚板で箱型に構策 \\
\hline & $E-1(2)$ & 主磿 & 3 階悹 & 北東 & 裹通り & 2 R & 1.5 間 & - & - \\
\hline 7 & $F-1$ & 扂庫 & 2 僣空 & 北 & 表通り & 4 尺 & 5 尺 & - & - \\
\hline 8 & $F-2$ & 畣庫 & 2 僣空 & 北 & 敖地内 & $4 R$ & 5 尺 & - & - \\
\hline 9 & $F-3$ & 主嬮 & 2 陵㥶 & 北 & 臯通り & 3 尺 & 1.5 周 & - & - \\
\hline 10 & $F-4$ & 主赝 & 入口左脇 & 裹南 & 臊道 & 2 R & 4 尺 & - & 㹂板張以横栈押え \\
\hline 11 & $F-5$ & 主尿 & 2 階窎 & 北 & 表通り & 2 尺 & 4 尺 & - & - \\
\hline 12 & $F-6$ & 會庫 & 2 階空 & 北東 & 表通り & 3 尺 & 1 間 & なL & 一枚板で箱型に棰築 \\
\hline 13 & $F-7$ & 庫庫 & 2 陵密 & - & 噰地内 & 2 R & 4 尺 & - & - \\
\hline 14 & $\mathrm{G}-1$ & 蒼庫 & 3 陵密 & 庽 & 敷地内 & 3 尺 & 3 尺 & - & - \\
\hline 15 & $\mathrm{H}-1$ & 主塬 & 1 踏空 & 扎 & 数地内 & 3 尺 & 1.5 間 & 2 尺 & 板張りトラス栈押え \\
\hline 16 & $\mathrm{I}-1$ & 石蔵 & 2 階空 & - & 敷地内 & 5 尺 & $5 R$ & & 板張り格子栈押え \\
\hline
\end{tabular}



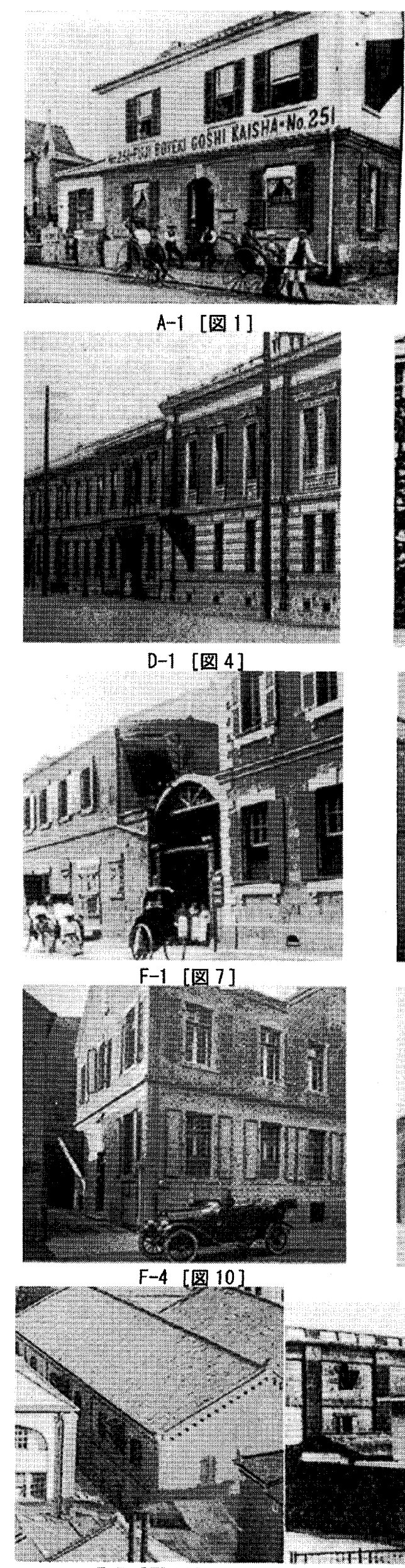

F-7 [図 13]

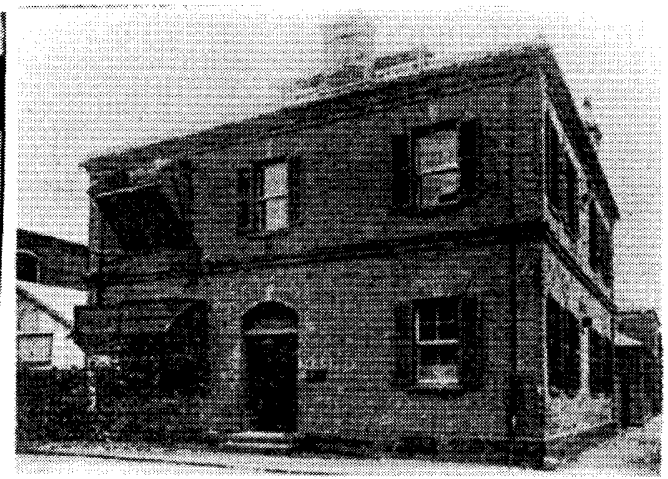

B-1 [図 2]

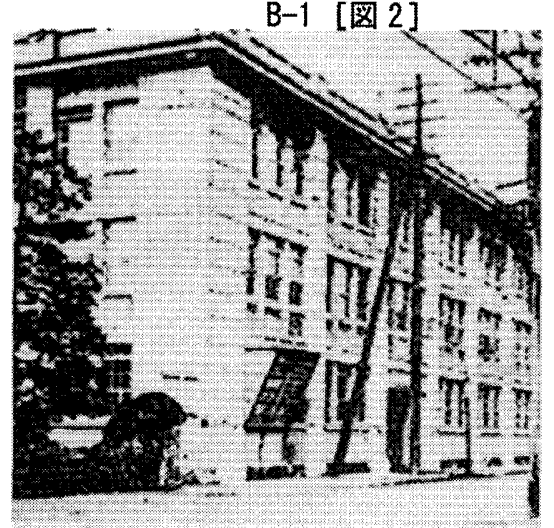

D-2 [图 5]

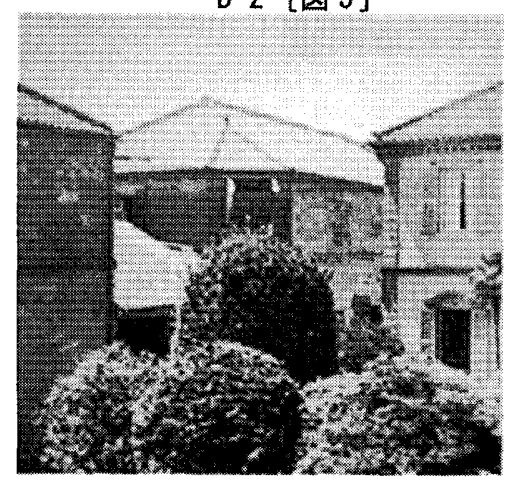

F-2 [図 8]

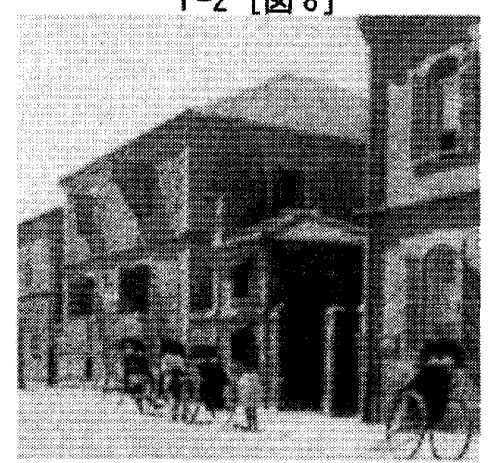

F-5 [図 11]

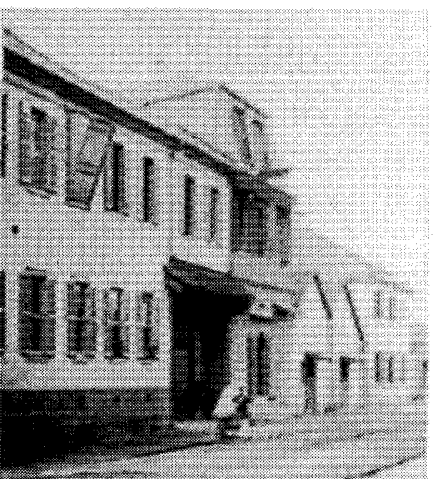

C-1 [图 3]
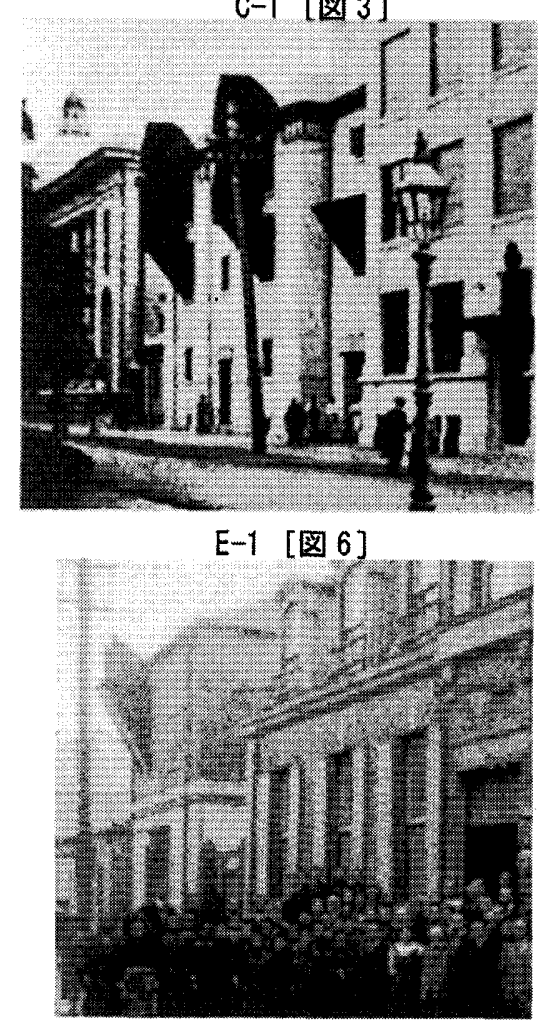

F-3 [図 9]

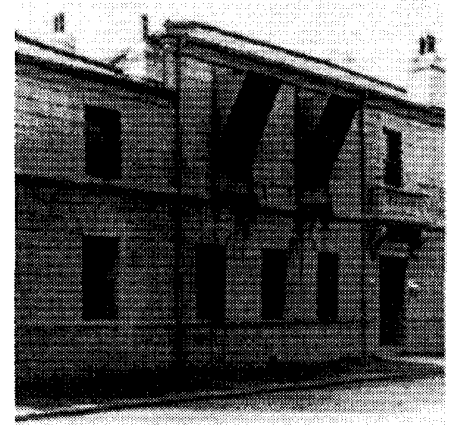

$F-6$ [图 12]

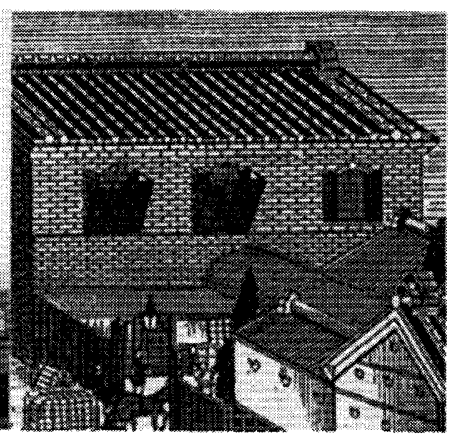

I-1[图16]

H-1［図 15] 
方位は、C-1、F-4、G-1 が北に向かないのは、地割から北面する ことはできないためである。検査仕様に記されているように、基本 的には北向きである。

幅は、室内の反射光線を防ぐため、検查に必要な最小限の幅を設 定したと推定される。関東大震災以前の横浜における建物の構造は、 A-1、F-1、F-2、F-4 6、I-1のように、多くが組積造であった。こ のため、構造上広い空幅の確保が難しかった可能性もある。

側面形状については、三角形を中心とする。角度は、検査仕様に 記された 45 度ではないものが多い。

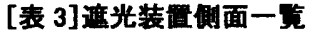

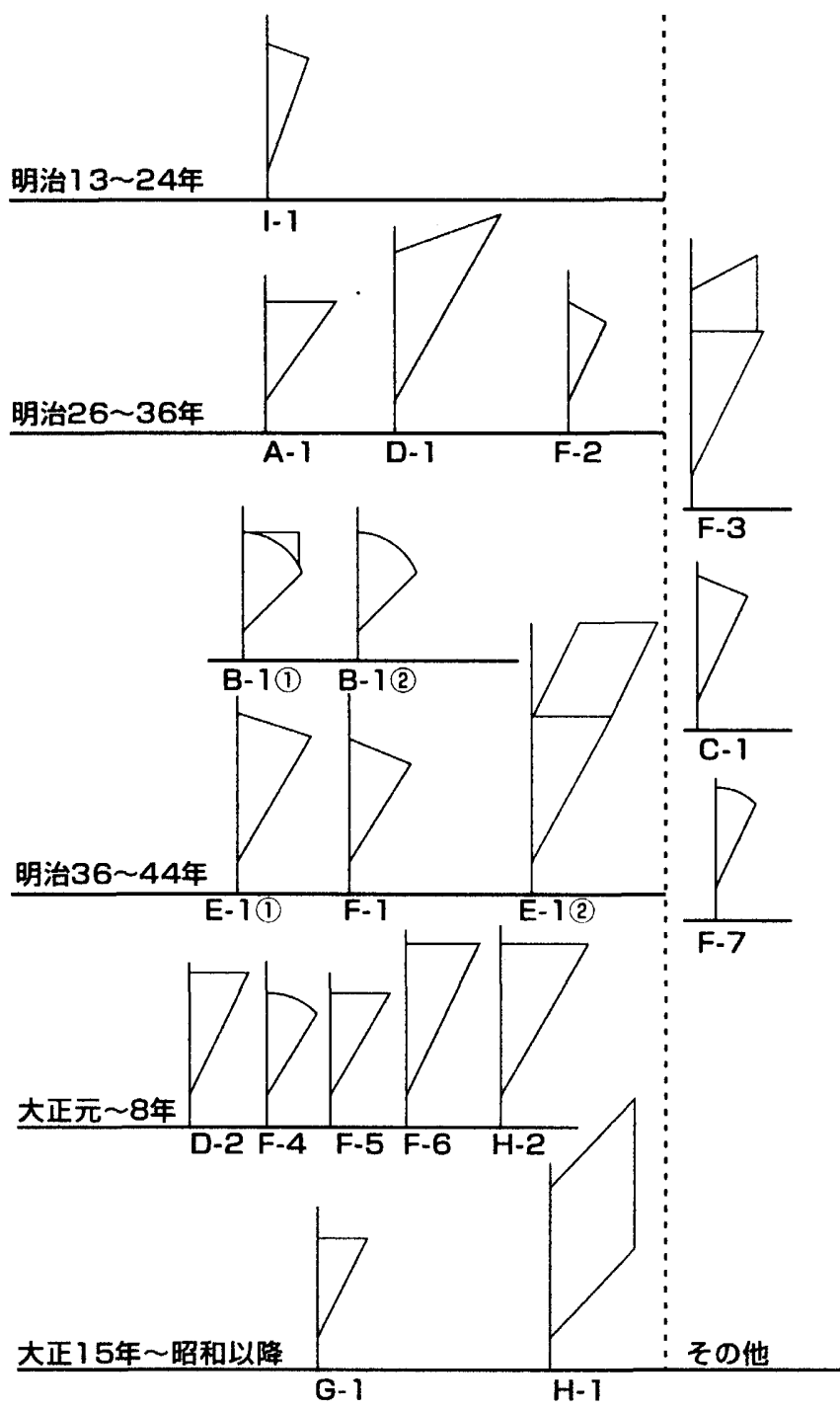

\section{4 検查所の設置とその影䧉}

遮光装置の普及に関係すると思われるものに検查所（D-1）の設 置がある。

検査所の設置は、明治 28 年 6 月発布の生系検查所法による。こ こから、生系の正量・品位検査 ${ }^{14)}$ が実施される。同年 7 月に生系検 查所の官制が発布、明治 29 年 4 月に生系検查法が実施され、8 月に 検查所が開始し、翌年 4 月に生系直輸出法が発布される。

[図 17] は設置当初の検查所の姿である。検査所は明治 34 年に
増筑される。増築は、検查所に隣接する横浜貿易倉庫の空地を借り 足して行われる 15)。[図 17］の正面入口の右手 [図 18］に増筑され た状況が D-1 である。［図 17］には遮光装置が設けられていないの で、検査所では明治 34 年の増筑時に初めて設けられたことになる。

『横浜生系検査所六十年史』（以下、「六十年史」と呼ぶ。）による と ${ }^{16)}$ 、明治 29 年 8 月 5 日の業務開始とともに肉眼検查が始められ る。当時、検查所は、検查部 3 科、事務部 2 科に分かれていた。検 查部第 1 科が受検生系の総受付と原量検查及び肉眼検查であった。

検查法規定には、「品位検査請求に対し受附けたる生綵を先づ肉 眼鑑定を施す（中略）最も必要となる条件」で、重要な険査項目に 「一,色沢 二,手触 (省略)」などがあげられている。これらは、前 記の肉眼検査と同様である。更に、「附記」として、「肉眼鑑定は生 系買方に於て最も重要なる条件であって開港以来外国商館にはこれ に堪能なる技術者を配置していた。手合せに於て先づ拝見と称し、 この拝見に及第しなければ商談は成立しない」としている。

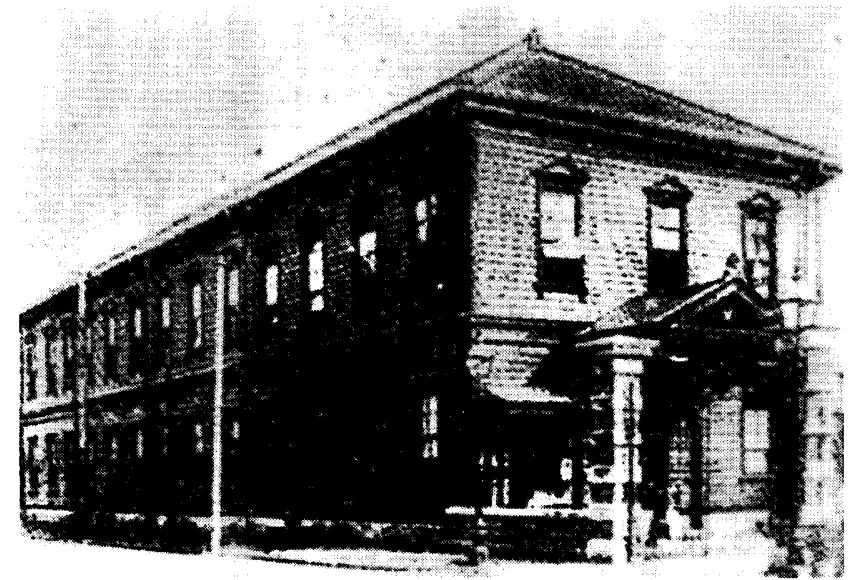

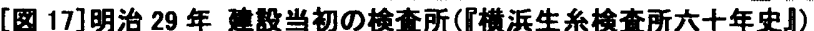

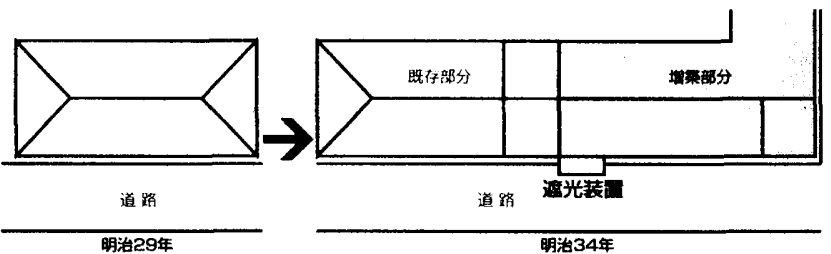

[图 18]明治 34 年 検㚗所の增筑配置图

また、「(明治) 三十四年には前年より正量検査は四倍の増加とな り(中略)検查室の狭㿽(中略)を告ぐるようになったので愈々明治三 十四年には(中略)正量検査室の増築を行わねばならざる」と、明治 34 年に検査所を增築した理由も記している。

このことから、明治 34 年に遮光装置が設けられたのは、単に検 査を行うためではなく、検查量の増加に対応するためだったと考え られる。また、[表 1] では、明治 34 年以降に設置されたものが相 当数認められる。この点から見ると、多くの遮光装置は検査所の増 築以降であり、検查所につくられた遮光装置を契機に流行した可能 性が高い。

\section{5 初期の生系検㚗之遮光装置}

次に、横浜における生系検査と遮光装置の関係を検討してみよう。 横浜における初期の生系検査 17)についていえば、当時、横浜の商 社では独自の検查が行われていた。昭和 41 年『検查時報 No.205』 
の座談会、六十年史では ${ }^{18)}$

初めは現在あるような生糸検査が行われず肉眼検査一本で生系の 判定がなされていた。(中略) 昔、商社で行っていた拝見と今日、 生糸検查所でなされる総荷検査とは行き方が違っている。商社に よってもそれぞれ流儀があったようだ。

生絲買入の外国商館各自に於て彼等が欧州に於ける生絲売買上の 経験に基く肉眼鑑定を試みて品質を鑑別

と述べている。このように、初期の輸出生系の検查は商社ごとに方 法が異なり、共通の方法を持たなかった。検査所は商社の要求する 項目の検查を行うのみであった ${ }^{19)}$ 。開港と生系貿易 中巻』では、

外國商館の番頭が問屋へ巡って來て持荷を間合すと問屋の番頭は 見本生係一括乃至數括を示し直段の折衝を爲し荷主への照會値段 に折合へば手合と稱し互にポンポンポンと三たび拍手する、斯く て荷物の全部を商館の倉庫に引込み一部分器械検査に附し成績可 ければ總荷を解き肉眼検查を行ふ、之を拝見と稱している ${ }^{20)}$

と、商社の肉眼検查について触れ、初期の検查方法に加え、E-1 同 様に「拝見」という言葉を用いている。

このように、初期の輸出生糸の検查は、商社によって異なり、方 法が確立されていなかったことがわかる。つまり、明治 20 年代初 頭に遮光装置がほとんどみられなかったのは、遮光装置を使った検 查法が確立していなかったことがその原因として考えられる。

検查法の確立は、明治 28 年 6 月発布の生系検查所法に始まる。 同法は、検査所の設置によって、商社で行われていた多様な検査法 の取りまとめをはかったと考えてよい。検査所の必要性が諨われる のは、明治 25 年奛系業振興会網領である。そこでは、四.検査所を

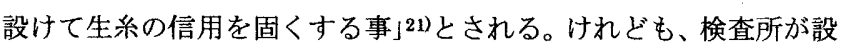
置された明治 28 年に遮光装置が無いことから、この時には遮光装 置を使った検査法が確立されていなかったことになる。

検查所は設㯰されたが、当時は任意検查制度で商社を拘束する力 はなかった 22)。しかし、「自明治三十二年至同四十一年各年間売込

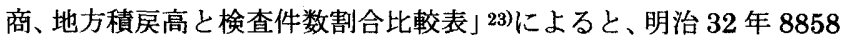
件、翌年 9418 件、明治 34 年 31901 件と急增する。明治 34 年は検 查所が増筑され、遮光装置（D-1）が設置された年である。つまり、 検査量の増加によって検查方法を改良する必要性が生し、遮光装置 を使った検査方法が導入されたのではないだろうか 24)。

輸出量の増加は、独自に検查を行っていた商社にも、検査量の増 加をもたらした。そこで商社は、検査所と同じ検查を行うことで、 その增加に対応したと考えられる。そして、検查所に遮光装置が設 置されると、商社もそれに做って遮光装置を設けたのではないだろ うか。ちなみに、検査所と同じ装置を設けることは、商社が自らの 検査の正当性をアピールする上でも効果的だったと想像される。

こうして遮光装置が普及したと考えると、[表 1]で設置年代が明 治 34 年より遡る可能性があるとした A-1、C-1、F-2、F-3、F-7 も、
明治 34 年以降に遮光装置を設けたとみてよいものと考えられる。 I-1については、明治 13 年の創業時から茶も同時に扱っている。こ のため、次項で触れる前稿 25) で述べた茶輸出の日除けであった可 能性が高いので、時代が遡ったものと考えられる。

その後、「横浜港主要輸出品輸出額」、「全国生系生産統計」による と 26)、明治 39 年を境に横浜の生系輸出が急增する。前記の検査件 数も同様である。検査方法の改良と遮光装置の普及が、こうした検 查数の増加を可能にしたのではないだろうか。

なお、検查が軌道にのると任意検查制度では互いに損失を招く恐 れがあるとして、検査所を第三者として格付し審査を行うことの義 務化が検討される。昭和 6 年 1 月、輸出生系㭘査法改正とともに、 輸出生糸検査法施行規則が発布され、昭和 7 年 1 月から実施される。 輸出生系の検査に対して検查所が強制権を持つのは、これ以降であ る 27)。この時、検查所には、大量の検査に対応寸るため、多くの遮 光装置が設置されている [図 15]。

\section{6 横浜における生系輸出の遮光䒾置と茶輸出の日除け}

横浜では、遮光装置と似た建築設備が、茶輸出に関わる商社や商 家等にもみられた。その設備が、静岡で「日除け」(以下、茶輸出に 関わる設備を「日除け」と呼ぶ）と呼ばれたことは既に報告した ${ }^{28)}$ 。 ここでは遮光装置と日除けとの関倸を検討しておきたい。

旧稿から日除けの特徵・仕様等をまとめると以下のようになる。

日除けは、茶葉の輸出審査を行う建築設備である。北方のガラス 空に設置し、黒塗の板を軒に向かって 60 度の角度で斜めに $3 \sim 4$ 尺 突き出寸という大正 4 年の標準仕様がある。標淮仕様には設置場所 や幅は特に定められていない。横浜では日除けが明治 16 年以降に 普及する。その害態は、(1)設置場所は表通りに面した主屋の 1 階に 多く、(2)高さは 3 尺前後、(3)幅は 1 間前後、(4)側面形状は三角形で、 (5)軒に向かって約 60 度の角度で突き出すという特徵がある。

日除けの標準仕様と横浜での実態を、遮光装置の検査仕様と横浜 での実態と比較したものが [表 4] である。

ともに仕様と実態は類似するが、日除けの高さ、幅と側面形状、 遮光装置の幅と突き出し角度は、仕様と寒態が一致しない。

標淮仕様と検査仕様を比較すると、寸法の明記の有無という違い はあるが、基本的な仕様は類似することがわかる。異なるのは、突 き出す角度と側面形状で、日除けは 60 度で台形、遮光装置は 45 度 で斜めに突き出すとあるので三角形と考えられる。

横浜における日除けと遮光装固を比較すると、方位や突き出す角 度、側面形状は類似する。異なるのは、設置場所が日除けは 1 階で 遮光装置は 2 階以上、高さが日除けは低く遮光装置は高い、幅が日 除けは広く遮光装置は狭いことがあげられる。また、日除けの普及 は、遮光装置の普及より早かったことがわかる。

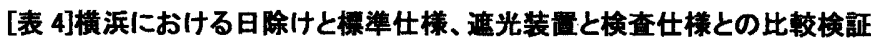

\begin{tabular}{|c|c|c|c|c|c|c|c|c|c|}
\hline & \multirow[b]{2}{*}{ 方位 } & \multirow[b]{2}{*}{ 堹所 } & \multirow[b]{2}{*}{ 遮光部分 } & \multirow[b]{2}{*}{ 色 } & \multicolumn{4}{|c|}{ 形状 } & \multirow[b]{2}{*}{ 锗 考 } \\
\hline & & & & & 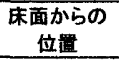 & 高さ & 䍣 & 笑き出し角度 & \\
\hline 日除け仕㥞 & 北方 & 悹を設け & $\begin{array}{c}\text { 東西南の三面は壁或 } \\
\text { は板 }\end{array}$ & 黒 & 高三尺内外 & 四尺二寸 & 三四尺 & 静六十度 & 悀面形状は台形 \\
\hline 实態 & 北方 & $\begin{array}{l}\text { 壁に二悹を設け、1 } \\
\text { 階に多い。 }\end{array}$ & 三方は板張り & 黒 & - & $\begin{array}{l}\text { 悹は不明。日除 } \\
\text { けは三尺前後。 }\end{array}$ & $\begin{array}{c}1 \text { 間前 } \\
\text { 後 } \\
\end{array}$ & 的六十度 & 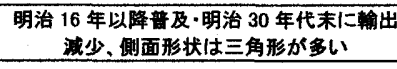 \\
\hline 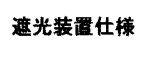 & 北方 & 壁に葖を設け & 他の三方は黒镂張り & 黒 & 約三尺 & 約四尺大对 & 䄪四尺 & 四十五度 & $\begin{array}{l}\text { 制面形状は三角形で、45度で上部に䋘めに } \\
\text { 向かってて突きさす }\end{array}$ \\
\hline 实態 & 北方 & 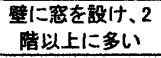 & 三方は扳張り & 里 & - & $\begin{array}{l}\text { 窥は不明。遮光 } \\
\text { 装遗は四尺以上 }\end{array}$ & $\begin{array}{l}=\text { 二R以 } \\
\quad \mathrm{T}\end{array}$ & 散六十度 & $\begin{array}{c}\text { 明治 } 34 \text { 年以降普及 } \\
\text { 倒面形状は三角形に近いか、上部は多様 }\end{array}$ \\
\hline
\end{tabular}

※[-] 不明 
このように、日除けと遮光装置は、輸出に関わる検査設備という 共通の役割を持ち、仕様や実態に類似点が多くみられるが、普及時 期や詳細については違いがあることがわかる。

注目されるのは、普及時期の違いである。とくに、遮光装置が普 及し始めた頃、日除けの役割が減じたと考えられることである。「横 浜港主要輸出品輸出額」によると、明治 36 年にピークを迎えた茶 葉の輸出は、明治 39 年には前年の約半分となる。ちょうどこの頃、 生系は徐々に輸出量を伸ばし、遮光装置が普及する。

この状況から判断すると、遮光装置は日除けを転用したり真似た りしてつくられた可能性がある。この裹付けとして注目できるのが、 実態の側面形状と突き出し角度が似ることである。これらは、両方 の仕様の相違点であり、かつ、仕様と実態が異なった简所であった。

一方、実態において、設置場所、高さ、幅が異なることからする と、遮光装置は日除けを単に転用したり真似たりしたのではなく、 参考にしつつも、異なる設備として出来上がったという見方もでき る。それでは、設置場所、高さ、幅が異なるのはなぜだろうか。

設置場所については、先に述べたように、生系では広大な荷解き 場が必要だったため、遮光装㯰を 2 階に設㯰しなければならなかっ たのではないかと考えられる。

高さと幅は、検査用の光と関係すると考えられる。幅が広いと光 を取り入れることが容易だが、幅が狭いと光を取り入れにくくなる。 一方、幅を狭くして高さを高くすると、光の入射角が調整できる。 遮光装置は、日除けよりも高さが高く、幅が狭い。これは、生系の 検査では、茶葉の検査よりも、絞り込んで調整した光を入れること が要求されたことを意味するのではないだろうか。この点では、遮 光装置の設置場所が 2 階にあるのも、より安定した光を必要とした という見方ができる。これに対して、茶葉の検査では、拝見台とい う台に幾つかの茶見本を並べて審査する。このため、日除けの幅が 広いのは、光の入射よりも幅広い光を必要としたということも影響 しただろう。

幅については、建物の構造とも関係するものと思われる。日除け の多くは、開口部の確保が容易な木造に付設されている。木造の柱 間は 1 間であり、そこに日除けを取り付けると、幅は 1 間に近づく。 一方、遮光装置は先に見た通り、組積造への付設例が多く、大きな 開口部には取り付けにくかった。

以上の違いを考えると、明治 20 年代以前は I - 1 のように、茶の 輸出用として使用していた日除けを、商館などが生系と兼用で使用 したことがあった。けれども、明治 20 年代以降は、生系専用の遮 光装置が日除けを参考にしながら、生系用の独自の検査設備として 考案されたと解釈できるのではないだろうか。

\section{7 結び}

本稿では、横浜の輸出生系の検査に関わる建築にみられた遮光装 置について以下のことを明らかとした。

(1) 遮光装置は明治 20 年代初頭まで遡るものは少なく、明治 30 年代 から昭和初期まで幅広い時代に見られ、昭和初期には標準的な仕 様も確立していたこと。

(2)遮光装置の多くは、建物の北側の 2 階にあり、幅 $3 \sim 4$ 尺、高さ $4 \sim 5$ 尺、側面形状が三角形に近く、角度が 60 度で突き出す形 になっていたこと。
(3)遮光装置は、明治 34 年の生系検査所增築時に設置され、それを 契機に普及したと推定されること。

(4)遮光装置の設置の背景には、生系検査方法の確立と生系輸出の増 加にともなう検査量の増加があったこと。

(5)遮光装置は、茶葉の輸出審査のための建築設備である「日除け」

を参考にしてつくった可能性があること

(6)遮光装置と日除けは、類似点が多いが、設置場所、高さ、幅につ いて違いがみられ、検査設備として異なる点もあること

本稿では、産業に関わる建築物に取り付けられた細かな建築設備 に着目した。そして、そうした設備が産業の変僄と深く関倸してお り、産業に関わる建築物の特徵をあらわすもののひとつであること を、明らかにできた。また、他の産業に関わる建物の類似した設備 と比較検討することによって、両者の関係や相違点を明らかにする ことができた。このことは、産業に関わる建築物の歴史研究におけ る、設備に対する注目の必要性を物語っている。

なお、本稿では横浜における遮光装置のみに注目したが、他地域 での生系検査設備の様子については、今後の課題である。

<謝辞〉文化庁建造物課の堀勇良博士、前農林水産消費技術センター横浜七 ンター消費検査部の宮下昌則技術研究官には、生系资料及び検查方法につい てのご教示をいただいた。文末ではあるが記して感謝の意を表したい。

\section{考文离}

1) 生系改会社規則,国立国会図書館蔵, 1873

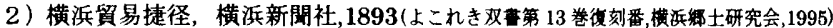

3) THE JAPAN ADVERTISER DIRECTORY,ADVERTISER PUBLISHINGCO.,1903

4）明治四十一年生絲検查所報告,農商務省生絲検査所,1909.6.11

5）スレート商会写真張，横浜開港资料館提供资料, 1909

6) 肥傢竜横活開港五十年史 下巻,横浜商業会議所,1909

7) 実業之横浜, 1911.10

8) 日本建策学会:建築雓誌 305 号, 1912

9 ）静岡県立鹿事試鈋場茶業部・静岡県茶業組合連合会議所共著:茶業全書, 静岡県茶業組合連合会議所, 1915

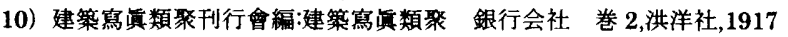

11) MORTON-CAMERON.W.H.PRESENT DAY IMPRESSIONS OF JAPAN,Globe Encyclopedia, 1919

12）生系検査所廳舎並二會莗新営概要，営縓管財局横浜出張所生系検所,1926

13）吉村定雄:生系品位検查並に格付の実際,明文堂,1933

14）本田岩次郎・日本虫系業会編: 日本亘系業史 第二巻,1935

15）棚㛢㤵三:現代日本工業全集 8 生系, 日本評論社, 1936

16）藤本実也:開港と生系貿易 上巻,開港と生系貿易刊行会,1939

17）藤本寅也:開港と生系貿易 中巻,開港と生系貿易刊行会,1939

18）藤本実也:開港と生系貿易 下巻,開港と生系貿易刊行会,1939

19）横浜生系検查所六十年史,農林省横浜生系検查所,1959

20）横浜生系検查所編:検查時報 No.164,横浜生系問屋協会, 1962.7

21）生系検查格付の変要（生系険查制度調查（2），農林省虫系局,1963

22）横浜市史 第 4 巻上,横浜市, 1965

23）横浜生采検査所編:生系の総荷検查(肉眼検查)を語る I, 検查時報 No.205,1966.1

24）蟫系技術第 80 号, 1971.9,蛋系技術研究会

25）神奈川県立博物館編：横演銈版画 文明開化期の建筑，有隣堂, 1982.12

26）小自直紀:三井物産初代社長,中央公論社, 1985

27）建設省関東地方建設局営纉部監修: 横浜生系検查所建設記録, 財団法人建 築保全センター, 1992

28）横浜開港資料館編:図説横浜外国人居留地,有隣堂, 1998.3

29）生系検査のはなし,農林水産省横浜農林水産消費技術センター・神戸農林 水産消費技術センター

30）横浜開港凟料館·財)横浜開港资料普及協会編:横浜もののはじめ考,(財) 横浜開港資料普及協会, 1988.3 .25

注

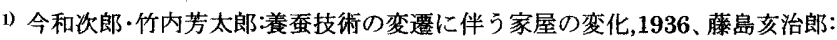
日本の建筑,至文堂,1958、伊藤鄭爾:民家は生きてきた,美術出版会 1963

他

2) 吉田鋼市氏の著書の他、塚田景他の都市史的な一連の研究ほか

3）堀勇良: 细横浜生系検查所(横浜地方検察庁) 广含解体調查報告,横浜開港資料 館紀要第 1 号,横浜開港資料館, 1983 ほか

4) 文献 13）「肉眼検査 $\mathrm{p} 29$ 
5) 文献 21)「肉眼検查 p4]

6) 生糸の検査方法は呼称・内容の変化が多く、文献 22) に詳しい。昭和 7 年 に輸出生系検查法が施行される以前、正規には肉眼検査と呼ばれていた。 昭和 10 年輸出生系検査法が改正され、総荷検查と改称される。

7) 文献 25）は『横浜諸会社諸商店之図』と『日本絵入商人録』（明治 19 年 6 月）の二部構成である。後書からは明確な遮光装置は確認出来なかった。

8) 明治 42 年刊行の文献 6) には遮光装置が設置されていない写真が揭載され ている。これは、もともと南東にあった遮光装置を北側に設置し改めたか らと考えられる。文献 19）によると、「明治四十年には予算三万二千円を もって本所の第三次搪張を断行するに至った。即ち品位部裹側に煉瓦造三 階建建物を增築し品位検查室の拡張を主とし其の他諸設備を増加し（以下 省略)」と、品位部の裹側に品位検查室を主に増築したことが記されている。 この時期は文献 6）の時期以前なので、この際遮光装漛を北側に移転した ものと考えられる。

9) 文献 8)「三井物産会社横浜支店新築要領 p 54」、文献 23)「名称は肉眼 桧査加総荷㭘査か $\mathrm{p} 1$ 1。前掲・宮下昌則技術研究官・石黒善夫博士人の七 アリングによると、生系検査に用いる空は「扯見空」と呼んだという。

10) 鎧戸が描がれているため遮光装慻のような外部装置は設置できず、すべり 出し空の可能性が高い。

11) 文献 29）によると、1 括は 24 かせ。1 かせの重さは約 $210 \mathrm{~g}$ である。括解 とは、括を解く作業のことである。

12）文献 12) , p2

13) 文献 23）「天然光線と人口光線による生系の見え方 $\mathrm{pp} 4 \sim 5$ 」
14）正量検查は、荷口の各俵・各ケースの正量を調べる検查。品位検查は、粉 荷整理検査と料系桧查がある。料系険查は、生系の再繰作業で、糸が切れ た回数を調べる検查や重さ、太さを計り、ばらつきを調べる検查

15）文献 19）「第二次拡張と正量検查室 $\mathrm{p} 83$ 」

16）文献 19）「検查法規定 $p p 19 \sim 20$ ]

17）文献 19）「生系取締と検查 $\mathrm{p} 2$ 」横浜では明治 2 年 9 月民部省が掻卵紙生 系改所を設置。明治 6 年 1 月生系製造取締規則の発布。同年 6 月生系改会 社設立 (同 12 年解散)。文献 1 ) には肉眼検查の記述は見られない。

18）文献 23）「総荷検查の目的 $\mathrm{pp} 2 \sim 4$ 」、「昔の肉眼検查あれこれ $\mathrm{pp} 7 \sim 8$ 」

19）文献 19）「生糸検査法の沿革 p159」

20) 文献 17）,p624

21) 文献 18）「生系值輸出の利害 p555」

22）文献 13）「直輸出之商権回復 p349」、文献 24）,中村富隆:生系検查の歴 史的役割と今後の方向 $\mathrm{pp} 7 \sim 11$

23) 文献 4)「検査件数 p4」

24) 文献 19)「第二次拡張と正量検查室 $\mathrm{p} 84$ 」明治 40 年には、棟瓦造 3 階建 の建物を増築、品位検査室の拡張を行う。

25）拙稿:横浜における静岡茶の輸出と日除けの発生について,計画系論文報告 集 558 号,2002.8

26）文献 20）「第 8 表 $\mathrm{p} 10$ 小、文献 22）,p258 次表

27) 文献 15)「輸出生采検查法 p178」

28）前揭:横浜における静岡茶の輸出と日除けの発生について、拙稿:静岡県の 茶産業に関わる建築に見られた日除けについて,計画系諭文報告集 547 号,2001.9、文献 9）「篦查場の構造 p264」参照 